\title{
Potential Youth's Civic Engagement on Virtual Public Sphere in Developing World
}

\author{
Khamis Juma Abdalla \\ PhD Student \\ Department of Journalism \\ Marmara University \\ Istanbul -Turkey \\ Email; binjumaa27@gmail.com \\ Turkey
}

\section{Abstract}

The emergence of new media with multiple platforms has abundantly adjusted the socio-political perspectives in such a way that our everyday conducts and professionalism point of views are entrenched over technological diffusion. The young people remain the potential users on the social media, considering their primary bases for daily accomplishments, owing to the novel features and realistic methods available. As an entry point, this paper intends to draw the conception of the public sphere, whereby the notion of publics is vital on abstracting the sphere of the internet, in which abundant spheres meant for the multiple clusters embark on political communication for their ways distinctly. It's the ideal realm which converges the peripheral spheres into the inclusive domain through communicative actions. In the developing countries, the youths along with minorities' engagement and reliance on the internet has been ominously mounting, comprehensive for political identities and rationalizing their civic opinions. Polling discussion on running candidates and political parties' manifestations are common during the general election and some diaspora communities and further foreign activists play a part in political affairs of the countries. Thus, this article aims at tracing the potential civil integrity for youths with political information efficacy fostered on digital public spheres, by which traditional media are politically run-downed, remoted by draconian legal framework and commercial determinants. Besides, this paper argues about the offline publics which are ideally distant, thus far implies to the narrow unitary sphere theorization owing to the technology division which so far entails partial civic life.

\section{Keyword's: Civic Engagement, Digital Public Sphere(s), Social Media, Political Information Efficacy, Youths' Citizenship}

\section{Methodology}

This paper utilized the qualitative approach through the descriptive analysis anchored in the theoretical methodology of civic deliberation through the conception of the public sphere. Its foremost established in the novel school of thought of the public sphere in the scope of internet infrastructures, featuring civic engagement, assurance of youths' communicative power along with distinctive characteristics which nurture political information efficacy to realize the civic needs. Commencing the primary conspicuous works of polity and ideology in the 20th century of the Italian Communist Antonio Gramsci, through his dominant notion of 'hegemony' and the 'manufacture of consent'. He viewed 'society' under the capitalist control as in two discernible forms; 'political society' which is 'hegemony' and 'civil society' where interdepend spheres found, accounting for the 'manufacture of consent' (Gramsci 1971). To him, civil society sticks at a common domain where the heterogeneous realms reach consensus through ideas and beliefs produced and reformed meant for 'manufacture consent' and legitimacy with the aid of the media, universities and religious institutions (ibid). Hence, civil entities are ideally systematized in the consensus of common good irrespective of the diversity. While 'hegemony' is set up more influential institution hitherto over the civil Society, having a supplementary command to falsify the political actions of civil Society. Consequently, the modern conception of civil society appears in the marginal public sphere with limited civic forces which are merely influenced by a number of economic and social factors, undermining the sense of social cohesion.

The second thesis is of initial pioneer of typical Public sphere theory Habermas (1989), he conceptualizes the public sphere as an ideal, a unitary domain where private individuals are involved in the vital civic decisions to reach their common interest, as the essential cause of democracy on the shared space 
(C) Center for Promoting Education and Research (Habermas, 1989). It's simply for such kind of equality in the sphere of miscellaneous clusters; the individuals discourage their private concerns for the matter of common good towards the ultimate public interest. However, Habermas (1989) further came to review his first work of The Structural Transformation of the Public Sphere which explores the progress of the bourgeois public sphere and its consequent transformation. Subsequent to many critics from various authors (inter alia, Fraser 1992) who argue that public sphere conception should not ignore the multiple spheres existing along with the common domain. Consequently, Habermas (1996) puts forward a 'communicative action' concept in which he recognizes diverse provinces and discursive interactional course which is fostered through communicative processes over consuming media and individual interactions to adopt the civic progression on their domains (Habermas, 1996). A particular public sphere appears significantly to maintain mutual trusts and benefits within the community through social movements in empowering the inferior ones (Fraser 1992).

Besides, Day and Schuler (2004) view public sphere in three characteristics. The first is to mean communication opportunities in a broad sense, where citizens engage in conversation by a variety of devices, including journalistic tools like newspapers, radio, and $\mathrm{TV}$, as well as face-to-face ways which can take place in the particular places like in coffee shops, public meetings or through other selected networks. Secondly, public spheres are "public" for a wide range of "spaces" where accessible to public exclusive of discrimination on the basis of nationality, religion, gender, physical appearance, political affiliation, ages, ethnicity, occupation, mental capacity, sexual orientation, and economic status, instead is open to all public. Thirdly, a public sphere mediates between people and institutions like political parties, the media, NGO and other government institutions for the intention to clear out the variations, example between leaders and those powerless by giving voice to the voiceless (ibid). Based on these three features, possibly the wired platforms correspond to the networked structures where the strong, the political public sphere and the weaker, the informal public sphere are interconnected by means of the communicative network (Friedland, Thomas \& Hernando, 2006). The media information system, especially the multiplicity of realms of new media geared on the internet infrastructures remains dynamic in the creation of civic debate and shaping the public opinions certainly.
WWW.cpernet.org

\section{Fostering Information efficacy over the Virtual Public Sphere(s)}

From the mid of the 20th century, the media and communication industry came into experiencing the significant structural transformation tracing information sharing in view of globalization, which turns the world into the ostensible single domain as put forward by McLuhan (1962) in his notion of 'Global Village'. This just commenced on the subsequent of the technological determinism, accounting for the extensive autonomy of information flows in excess of complex technological media. Yet, the question has to come across on the aftermath is that; what eventual village is constructed in the course of globalization? The village which is precisely structured over technological diffusion is premeditated with deficient consensus passing through the elusive systems, as the decentral modality of information society over industrial society tends to endorse a marginal instance for the survival of unitary sphere conception as ideally claimed by Habermas (1989; 16). As long as the industrial society unlikely survives as per informational society overwhelms the progress, in place of the individuals persisting on the strong contracts casually throughout commerce and other capital businesses in respect of their interests and mutual demands ${ }^{1}$.

Whilst, the multilayers are radically fostered on the scope of the internet sphere, it's implying to an erratic disposition of emerging space to engender the civil society into a broad approach of deliberative democracy, undermining the prospects of information efficacy meant for undemocratic participation counting assorted social entities from diverse backgrounds (Chen 2008; Weimann, 2006; Vincent, 2007; McLaughlin, 2003, Coleman 2005). Nonetheless, the wired sphere embraces the typology of social consumption of informational products including cultural properties and news accessible on the discursive space. Weimann (2006) admits the unique features of the internet that reinforce the public engagement through expansive modalities, such as emails, message boards, links, web pages, chat rooms, which fuel loads of information materials, as of evolving online discussion on public agendas (p. 75). Likewise, the public institutions and individuals go forward into dynamic architects in exercising the lively right to information and setting up various channels,

\footnotetext{
${ }^{1}$ Course Notes for Globalization and The Media, Global Köyü Anlamak, Ozcaglayan, Mehmet. Marmara University, The Institute of Social Sciences. Istanbul, 2016.
} 
(C) Center for Promoting Education and Research counting blogosphere which recently stands in a critique of communication and political revolution (AlRodhan, 2007). Whereas the entire access of information and even production tend to let users themselves to feed in and interpret the texts in the form of comments and questions as well as circulating further across the multiple domains, it's so far continually smoothing the progress of the civic discussion.

It's the impression of the internet that has emerged as a virtual and mysterious sphere, shaping the civil life whereby the peculiarities reflect the political culture and social movements addicted to the democratization. Howard (2011) insists that internet keeps on open and accessible sphere comprising pluralism and diversity of the voices, a crucial phenomenon and driving force for the expansion of civic lifecycle in the developing world specifically ( $\mathrm{p}$. 121). While Ogan and Cagiltay (2006) express their sympathetic ideas on the way that the civil society through Itiraf.com site can meet demand and integration of diverse citizens in Turkey (p. 12). It is abundantly used as logistical tools of widespread civic information with determinants (Vincent, 2007; 23), intended for cultivating political information efficacy on governing polity and civil society at large.

The freedom of traditional media as normally restricted by some ruling elites around the developing world, such as government obtrusive deliberation through filtration and censorships imposed to the minority politicians. Conversely, instead, social organizations and activists now are gifted to penetrate with accompanying methods of cyberactivism and hacktivism to reach the political goals ${ }^{2}$. For instance, Email and fax are ample alternative and communicative resources by many hostile groups to the states after their ordinary means being muzzled, along with social media accounts when interrupted by government intelligence. The practical examples are of the opposition organizers in Indonesia who brought down the Suharto Government, and when the PKK leader Abdullah Ocalan was detained by Turkish government official security, Kurdish activists managed to organize successful demonstrations in 22 different cities across Europe all the way through email and fax from Turkey (Wolcott and Goodman 2000; 39).

\footnotetext{
${ }^{2}$ Hacktivism; activists use for political purpose on the internet by means of hacker skills, mostly against censorship and filtering programs from the national installations, Cyberactivism; movement by individuals or groups tend to encourage free information access, they use a lot of effort to reach their goals prejudiced in many authoritarian government.
}

WWW.cpernet.org

As this is explicitly utilized across the world to justify the virtue of the digital sphere, as another example, in Tanzania where civil society organizations are conditioned to social initiatives solely rather than taking parting in political affairs. As accoutring to this, a number of Tanzanian civil organizations make use of the social media platforms as a replacement for their political movement, creating civic debate and criticizing the political misbehaviours among ruling elites. Such great tendency evolves intensely by the advocators and minority groups persist on digital spheres, as unconventional space to rise up the peripheral impressions of voiceless to the international access along with covering the domestic publics (Vincent, 2007). Ultimately, the modern political communications are radically armoured on the digital public domain, tenable though novel media tools, responding to the high number of emergent internet users who are active in miscellaneous online provinces in pursuing civic commitments.

Howard (2011) sights the opposition political party' presence online in many authoritarian governments that indicates the restrictions on the freedom and suppression by state-owned media in term of civic deliberation. Accordingly, left wings and other social activists find virtual manifestation potential to political communication in approaching their publics and as refrainment from suppressive mainstream media exposure. What is more, the development of technological infrastructure chains the presence of comprehensive news portal in various languages? Authorizing leftists in the countries of democratic transition and authoritarian to secure the diverse political information and appeal attractions to their domestic supporters, as well as to reach far all over the world as to gain politically backing from abroad, foreign journalists, and members of Diaspora communities in the direction to maintain global exposure. As per Egyptian experience for Muslim Brotherhood, Pakistan's People's Party, and Kazakhstan's Ak Zhol (Right Path) their websites were always kept up busy featuring electoral occurrence. However, for the massive political parties' communication online, the high technology diffusion is not a sufficient determinant to realize the civic need in the millennia. Turkey's political parties are very active online in providing their policy Manifestos and make available the news through political speeches, profiles of electoral candidates, and the voting records of legislators, while Bosnia, Lebanon, Montenegro, Russia, and Tanzania are prominent with wired political parties (Howard, 2011). 
The prevailing penetration that technology diffusion has put forward the detective structures headed for the political information efficacy is patent for the integrity of egalitarian tendency on the virtual sphere. Yet, it's skeptical whether this new form of communication sparks a typical democratic revolution (Barney, 2001) in a broad sense of freedom of expression. So long as communication and democracy are interchangeable phenomena under universal civil rights. In the last decades, politicians used to set up their casual spaces mainly through public gatherings in a given time and places, where dependence on mainstream media was significant vehicle campaigns on influencing supporters during the election and in other civic matters. Albeit, the contemporary role of media professionals in politics is surfacing into individuality rather than a totality of media outlets prior to professional codes and policies. Accordingly, political parties tend to hire autonomous media professionals with strategic methods on the basis of the compound structures available on new media to entrench civic awareness across their niche audiences and community at large. As far as such individualism in information sharing goes forward to embrace the political domain, the deliberate online discussion is unlike to signify the legitimacy of the democratic life (Thorseth and Ess, 2009).

\section{Potential Youth Civic Engagement on Social Media}

The young people's political influence might be traced through explicit public information keen on participatory framework along with decision-making towards active citizenry (Arches and Fleming, 2006: 85). Edwards (2008) considers youth participation in politics as a fundamental resolution entrenching the social inclusion over peripheral groups with social impediments (p. 17). The technology diffusion activates the nascent approach of social life amongst young people on information flows in creating liberal networked space. The new media system turns into dynamic information generator, inspiring the prevailing social system of communication, owing to the multiple platforms which engender widespread public information, with intents across the conflicting clusters. Individuals rely on this innovative way and method of communication for the potentiality to rationalize twoway communication more willingly than on the traditional media. Youths become addicted to such extent, expressly the adolescents tend to rely on social media for their daily accomplishments, because of distinctive features and formats which are limited to mainstream media. It's not to surprise that, the first thing nowadays when young people wake up every morning open mobile phones and get in touch with the friends of innumerable locations on Facebook, tweeter or other social media platforms, having a look on texts, video, or photos produced by friends, and accounting them through likes and comments and sharing. This progression evolves the Newspaper reading habits, mostly young generations at this instant prefer much to use their mobile phones and computers in reading newspapers online rather than buying the circulated copies on the street or in the shops (Güneş, 2006).

Hence the young people engagement to digital communication is astonishing, as long as their concerns to digital political communication are evolving across time. This gives notable implication to the youth activeness on their citizenship and political affairs in the developing countries in particular. In Africa, where the youth population is prominent, about 50 percent of the African population is under 20 years old (Unicef, 2014), most of them are eager now to get engaged in civic debate online. Facebook leads in popularities in many developing countries as an imperative sphere for political information and news distribution, especially among youths ${ }^{3}$. In Egypt, Facebook prominently hits the record for critical initiatives network of countless civic movements. McGrath (2009) writes that in April 2008 a large number of young woman's Facebook users formed a network demonstrated the plan in a strike on labor disputes, demanding sufficient payments at a national textile factory in Mahalla, Egypt. It was estimated 160,000 bloggers, and 12 million Egyptians were online, they commonly contributed and shared abundant texts, video, audio messages and pictures circulated mostly through YouTube, Flikr, Facebook, and Twitter (McGrath, 2009). In Kenya Young people engagement in the online civic debate is also growing dramatically. The young Kenyans who count 79 percent of the population are under 35 years, of which 47 percent their crucial civic discussion run on Facebook (Douai \& Olorunnisola, 2013). This is all about the adolescent awareness on politics, cultivating public deliberations

\footnotetext{
${ }^{3}$ A study investigating the relationship between youth engagement on social media and their interest in politics holds Facebook to be an important source for political information and news. Media Programme Sub-Sahara http://www.kas.de/medien-afrika/en/publications/42943/
} 
(C) Center for Promoting Education and Research keen on political life; especially during the national election and some civic comportment entail the politics of their countries.

Accordingly, the networked public space persistently deliberates keen on online political discussion. As in Tanzania where WhatsApp leads in popularity among the new platforms throughout the last General Election Campaign in October 2015. Countless political messages were shared across the country using this App; it's due to the suitability of this platform across assorted demographics (Global Voices, 2015). With other platforms, Tanzanian youths are growing into much sentient about the civic commitments during the recent election compared to previous elections held in the country. Right through various political parties' rallies, youths emerged to thump the number of audiences in the balloting. They also used Facebook, YouTube, WhatsApp, and Twitter sharing some messages of their political parties' candidates respecting the gatherings held in the different areas of the country. Again it indicates the youth mindfulness of the political debate that evolves across the time in Tanzanian politics. Comparatively, unlike now, during the first multiparty election in the 1990s, the civic culture was quite poor for 72 percent with fragile on political debates (Killian, 2008). To current the consciousness widespread along with the online discussion copied from the street to the universities, an abundant number of youths are much excited now in politics. For example, Secondary School students significantly emerge to deliberate their citizenry about mismanagements by government officials and other politicians (Lunat, 2008).

Likewise, civil society organizations have dynamic endeavors in community mobilization and setting agenda online for social and political accountability which so far mostly target youths' attention, nurturing the legitimacy on the civic life through online political discussions. It's obvious that information and communication technologies endow with a multiplicity of features and forms which afford new infrastructural conditions for young people all over the world, with numerous devices like cell phones, computers and tablets smooth the progress of political communication in the line of the real democratic world. This emerging prospect abandoned the traditional media provisions on account of some draconian laws and censorship pro the ruling elites which manifest the social exclusion including youths (Lüküslü, 2008). Eventually, online channels become massive in preference, consumed with
WWw.cpernet.org

political inputs in the midst of a variety of civic deliberations.

\section{The Internet Dichotomy of Minority Political Empowerment}

There are assorted concerns over the technology infrastructure whether strategic enough to meet the rations of prospering effective communication of polity and citizenship regarding the diversity natures available on the sphere. Barney (2001) argues the internet as a deficient public sphere which rarely affords civic power in respect to impartial egalitarianism in public life. According to him, some social groups especial of remote ethnicity which are politically marginalized, including women might be sternly isolated from online participation symbolically as per the normal social settings set them out (ibid). Likewise, Barney and Papacharis (2002) debate on the internet surveillance and control that merely cast down the public sphere notion, in view of the industrial capitalism that devastates the social power and hence deteriorate democratic principles throughout the wired sphere (p. 58). Moreover, McLuhan (1962) contends over categorical uniformity formed in a global village due to a variety of social scenarios and experiments within. In this sense, how the individuality manipulates into the structured global community as instantly acts according to personal characters based on unlike socio-political backgrounds? In light of the social cybernetic sphere which is created with a number of variabilities and divisions among the players as well as discontinuity of the customs and rules in such a way that no common projections may prosper, on accounts of mysterious occurrence in the particular manner that demoralize the foundations of the tranquillity of the ideal sphere (McLuhan, 1962). Nonetheless, the internet has an ironic account of universal discourse for the involvement of masses. Especially youths' sympathy aimed at the civic engagement in professing public life provisional in the course of information flows through liberal networked space. In the proportion of the potentiality to rationalize two-way communication rather than the traditional media in consequence of some draconian laws and censorship pro the governing system and elites.

With outstanding examples Howard (2011) affirms that internet becomes a significant domain of curtailing political partitions within the community, particularly in the developing world, nurturing the inclusive discourse in the citizenship flourish (p. 81). Citing several examples of women who are digitally 
(C) Center for Promoting Education and Research empowered in the Muslim community especial of the Gulf States, Howard (2011) affirms that the digital space triggers women's citizenry rather ahead than before. The oppressive viewpoints of stereotypes based on social norms and colonial traditional undertakings such as preventing from voting and participation in decision making like to be elected as Member of Parliament are currently discussed through online channels. Hitherto Howard (2011) explains about wired sphere which emerged to seal the longstanding breach of men political and social domination having had always treated women as submissive, inferior and obedient to men, as an alternative now internet grants a peculiar opportunity for women to voice up and participate abundantly in civic debate and device their citizenship (p. 83). For example, in Egypt nowadays technology infrastructure boosts women up in civic engagement than mainstream media do. In the past, girls were hardly ever registered after birth, The Egyptian Center for Women's Rights incorporation with World Bank managed the supporting venture for identity cards which ultimately used for voters' registration and other various access of public services (ibid. 86). Therefore, the internet presents heterogeneity point of views and backing the subordinate spheres for equality and revealing in public values keen on diversity on national and spiritual lines.

Nonetheless, the provision of deliberative democracy is predetermined by dint of effective communication for the public to have enough devices in the opinion formation and delivery (Goodman, 1998). The question might come across here is about the extent of indefinite individuals partaking with thoughts and values by means of excessive expression on the stage, to the scope that online participation may distress confidentiality, reliability, authenticity, and accuracy, warning the trust of communication media. Considering a mediate sphere of politics and social determinations in general, to what extent do politics and political communication has been affected by new medications in the practice of civic engagement in the developing countries? There is growing remarkable online civic engagement crosswise the communities, following several political parties and civil society organizations prioritize the internet as a replacement for their approaches to reaching far inclusive publics, counting journalists and other followers as well as ordinary citizens. This happens in their struggles on reaching the
WWW.cpernet.org

simultaneous publics effectively through online alternative.

The wired circle has also emerged to seal the ancient gap of elites' political and social domination which had treated the minorities as submissive, inferior and obedient to dominant spheres, instead, now it's the opportunity for women to voice up and participate abundantly in civic debate and device their citizenship (Howard, 2011). The marginalized groups who have access to the wired discussion are potential to gain citizenry exposure that further them to imaginable participation of offline sphere so far, they are likely to become active in economic and political arenas. In this digital age, Social conscience and movements are most prospective with the backing of technology, many developing countries utilize in supporting the social movements while left wings rest the most beneficiaries of this instalment (Wolcott and Goodman 2000; 43).

Conversely, the internet is also presumed an indefinite substructure for civil society practices in effect (Barney, 2001), as of information rich and poor concept, most of the digital operators are still social elites and urban settlers who have enough access of bandwidth liable to widespread their identical ideologies. According to Barney (2001), some social groups, especially of ethnic minorities who are politically marginalized, including women, are about to be sternly isolated from online participation symbolically as per the normal social settings set them out (p. 84). Despite the collaborative endeavors by the developing countries using the internet in the course of the social and political prosperities, the online representativeness signifies the virtual character debatable and likely challenging the suitability of being a common realm, taking example of Tanzania where the number of Internet users surpassed 23 Million (49\% of total population) across the country as of December 2017. This number indicates scarce envoy to the total population of over 47 million Tanzanians who would be prospectively barred from online civic communication. As long as civic forerunners struggle to overcome their political power over the informational domain, the capitalist control of the internet so far, favors the commercial elites impressively to handle the social space into profit-making point of view (Thorseth and Ess, 2009; 153), commencing the rising of the cultural commodities and media conglomeration. 
(C) Center for Promoting Education and Research

\section{Determining Public Agenda for Global Citizenship}

The globalization perceptive tends to inspire the world status-quo of integration anchored in information flows, on account of the diversity and pluralism in political agendas among the nation states, that so far rationalize diverse impressions yet to the universal point of view on citizenship (McLuhan, 1962). Local Community inclines to set up the considerable atmosphere in view of native desires, keen on strengthening their identity emotive to the promptness of globalization. The sociocultural variation on the observance of international standards of human rights, through a social movement, remains irrelevant on global cohesion. Thus, the earth persists on disparity for the sake of locality and regionalism, unless deliberate universal endeavors to take upon. Hamelink (1999) recommends that forming public opinions through educational technique are potential measures of observing the diversity considering the multicultural spheres in respect of universal civil rights, so that to turn into global citizenship, meant for eliminating the destruction by nation states over universal citizens' rights in structuring a perpetual global family.

Besides, Mainstream media are probable on creating multiple public agendas for the Global citizenship through communicative endeavors, internalizing the universal privileges from the community, together with advocating the equality in tracing the minorities at abroad and of local setting over the legal burdens, social treatment along with traditional stereotypes. This implication relies on the media distinctive role in setting the agenda to the society accountable for the multi-disciplinary prospects essential around tactical approaches of attracting the audiences to get involved at global competences and consciousness (McGrath, 2009). On the other hand, the current status of monopolized global media market sticks to demoralize the diversity and plural views, especially from minorities, as of migrations policies and indigenous attitudes which typically fore-gore the nationality approaches over foreign communities unevenly. This kind of media imperialism, which exist not only at the global level but also regional for the second tiers and national media concentration persevere the world polarization. Lacking a global agenda on the subject of the universal movements that typically clue to racism, ethnic divisions, and fundamentalism instead of the respect of universal moralities in the direction of nontoxic global interconnectedness (Coleman, 2005). www.cpernet.org

Likewise, the capitalist ownership of global media is behind so far to depress the flow of information counter to consistency which stuck worldwide media coverage based on the fragmentation of developed countries and in the third world countries.

Providing the new media play abundant role in building the comprehensive public agenda concerning the national and global current affairs in the line of civic engagement (Hamelink, 1999). The public is passive yet by the propagation of the agenda accounted in the society towards global agenda, in view that, the global media capitalism arranges for the identical contents on the digital sphere to be circulated widespread the new media platforms. Still, the professional attributes in mainstream media ought to pull the public attention to embark on the set agenda. In this way, the global agenda can start here with professionalism, thanks to some of the local matters have a great influence to the universal humanitarian point of view; this may frankly pull attempt of international involvement to the local context (Özkan, 2006). Alongside the Information flows an online, from the locality with reference to the social and political demand keen to the integration of global discourse which is drawn from diaspora communities and further foreign activists. Social organizations online and offline are informationally endeavoured by mainstream media steering on inclusive citizenship with common accountability.

Likewise, civil societies strive with plentiful strategies online through websites, blogs, social media pages which role as the common space loaded with diverse contents in the form of text, video, and pictures in generating the social mobilization concerning the civil rights through enormous civic debates over the virtual public domain. As the public are key generators of the content on these platforms in term of expressing their views and uploading several ideas as well as widespread the contents to others meant for plentiful sharing among them across the internet realm (Hamelink, 1999). In this manner, citizens themselves are prerequisite to global citizenship, in which they are ought to be equipped with the comprehensive mechanism by civic advocators in detecting the universal civil liberties. Over the world numerous local civil society organizations are fighting for the global recognition about their movement based on the existing socio-political situation in their local setting, thus far 
(C)Center for Promoting Education and Research the global citizenship calls for further endeavors into hominization of the overall multinational prosperities.

The liberations are at the heart of political settlement in compliance with civil societies to be in favor of the anthropological virtues of the local and global citizens (ibid). This should be addressed from taking into account the geopolitical concerns over global forum consistent with the typical public interest so far.

\section{Conclusion}

The ordination of the digital public sphere largely traces the conception of civil society and related perspectives keen on political communication and civic deliberation. The consequences of technology as a significant infrastructure for inclusive domains are generously hooked on diverse scholarly viewpoints. This paper highlighted the distinct concerns on the internet as merely fitting a broad sense of unitary public sphere, commencing the idealistic impression that the identical domain might converge the peripheral realms into common public space, designed for political information sharing and sophisticated the basic collective rights derived from inclusive communication as to observe the conflicting consensus athwart the common sphere. Whereas, the technology diffusion streamlines the heterogeneity by means of multi-layered spheres, advocating diverse and plural civic privileges according to their miscellaneous settings and peculiarities per cluster. In this insight, it's more vivid for the continuous ethnic and minority as of a women subordinate sphere, hooked on deliberation to get rid of social prejudices in view of the political and economic burdens, mobilizing them into civic engagement over the online civic realm.

This paper so far rendered to the earlier theory of civil society as a public sphere for the individuals to get involved in political arenas, as per political parties' internalization of the digital forum is certainly yet that the deliberative democracy mounts across the sphere. There are a remarkable number of political parties and civil society organizations with ridiculous approaches which cement the mutual trust and welfares to their publics across the world, setting the agenda and forming the opinions through the involvement of the public in the discourse. Whilst, Mass media roles as political actors in the democratic society in creating civic debate, at that juncture is to propagate worldwide so that to pursue global engagement. The power of media in shaping the public outlooks is starting with abundantly approaches in altering their attitudes in the direction of forming the public opinions in the critical discourse as of geopolitical integrations and global transformation. Due to the hostile legal framework to the scope of freedom of expression across the traditional media, whereby adequate exposure is merely secured to the ruling elites and commercials, the social accountability of media is uneven at the moment.

Subsequently, Technology diffusion provides the elegant opportunity for civil society movements in tracing the public through sophisticated devices such as computers, cell phones, and tablets to widespread emails, short messages, photos, and video, whereas community-acquired autonomy in expressing the progress of the polity and for pulling international attention to the domestic faulty. As the massive for civic engagement, especially for young people due to the potential and novel features and method over new media platforms. In due course young generation evolve into adoption to the digital political information efficacy, since the web 2.0 evolution grants them enough self-expression and exposition into a discussion of political agendas broadly. As a consequence, the evolving online public domain frankly approves social movements for advocacy institutions and even by aggressive deliberations over governments' burdens in the developing countries, in particular, they are amply gifted to facilitate in their ways headed for the real democratic world.

As long as politicians, journalists, and other activists make use of the online public realm in mobilizing publics athwart abundant civic debates, along with the utilization of information distribution concerning the socioeconomic demands anchored in the sociopolitical environment of the nation-states. Nevertheless, the online public sphere as viewed by some scholars is idealistic, right through the wide range of current capital communication tendency to create a new kind of sociological structures on the digital operation into their perspective. internet still rules out some minorities, especially in the developing countries where technology infrastructure is mostly exploited in urban while entire countries are not yet installed. This possibly denotes the digital divide in the communities and gives a bad impression for civil society online initiatives, when managing civic debates come into fruitless in place of equality point of view. It's also about geographical and economic 
partition, whereas only favorable for the communities of the certain terrestrial or social class incline beneficiaries of online public discussion. To this point, there should be comprehensive political settlements for our governments and civil societies to focus the remoted spheres, so far to pull them into their relevant spaces and involving in their citizenships.

\section{References}

Al-Rodhan, N.R.F. (2007), The Emergence of Blogs as a Fifth Estate and Their Security Implications, Geneva.

Arches, J., and Fleming J. (2006). Young people and social action: youth participation in The United Kingdom and United States. New Directions for Youth Development, 111, ss. 81-90.

Barney, D. (2001) Prometheus Wired: The Hope for Democracy in the Age of Network Technology, University of Chicago Press.

Chen (2008): "Uncovering the Dark Web: A Case Study of Jihad on the Web." Journalof the American Society for Information Science and Technology 59,

Coleman, S. (2005) Blogs and the New Politics of Listening, The Political Quarterly

Day, R. and Schuler D. (2004) Shaping the Network Society, The New Role of Civil Society in Cyberspace, The MIT Press.

Douai, A. \& Olorunnisola, A. (2013) New Media Influence on Social and Political Change in Africa, IGI Global, Hershey, Pennsylvania (USA).

Edwards, M. (2008), Civil Society, Polity Press, London.

Fraser, N. (1992), Rethinking the Public Sphere: A Contribution to the Critique of Actually Existing Democracy, in Calhoun Craig (ed.), Habermas and the Public Sphere, Campridge, MA: MIT Press, 109-142, 1992.

Friedland, Lewis A.; Hove, Thomas \& Rojas, Hernando, The Networked Public Sphere, Javnost-The Public 13: 4, 5-26, 2006

Global Voices, (2015). WhatsApp Leads in Popularity, But Not Substance in Tanzanian Election Campaign retrieved on January 11, 2016 https://globalvoices.org/2015/10/12/whatsapp-leads-in-popularity-but-not-substancein-tanzanian-election-campaign/

Goodman (1998), The Global Diffusion of the Internet Project: The Mosaic Group; SAIC. An Initial Inductive Study.

Gramsci, A. (1971), State and Civil Society, International Publishers, New York,

Güneş, S. (2006), Kitle Kültürü Demokrasi ve Medya, Enformasyon Toplumunun Putları, Ankara: Hece Yayıncılık, s. 127

Habermas, Jürgen, The Structural Transformation of the Public Sphere, Cambridge, MIT Press, 1989 [1962].

Habermas, J. (1992) Further Reflections on the Public Sphere, in: Calhoun, C. (Eds.) Habermas and the Public Sphere, 421-461, Cambridge, MA: MIT Press.

Howard, P.N (2011), The Digital Origins of Dictatorship and Democracy, Information Technology and Political Islam. Oxford University Press.

Killian, B (2008) The REDET discussion fora: A conceptual framework and historical context conceptual framework. In: Mlina A et al. Grassroots Democracy at Work in Tanzania. University of Dar es Salaam: REDET. 


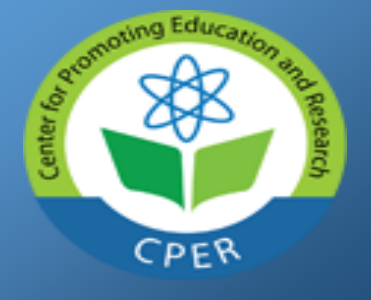

EISSN: 2469-6501

VOL: 5, ISSUE: 5

MAY/2019

DOI: 10.33642/ijbass.v5n5p3

https://ijbassnet.com/

(C) Center for Promoting Education and Research

WWW.cpernet.org

Lunat, Z. (2008), The Internet And The Public Sphere: Evidence From Civil Society In Developing Countries, The Electronic Journal On Information Systems In Developing Countries, retrieved on January 11, 2016 Http://Www.Ejisdc.Org/Ojs2/Index.Php/Ejisdc/Article/Viewfile/501/253

McGrath, Cam. "Egypt: Cyber Insurgency Rattles Regime.” InterPress Service, Ogan, C. and Cagiltay K. (2006) "Confession, Revelation and Storytelling: Patterns of Use on a Popular Turkish Website." New Media \& Society.

Thorseth, M. and Ess, (2009), Technology in a Multicultural and Global Society, Norwegian University of Science and Technology, Trondheim, Norway

UNICEF (2014), Generation 2030|Africa, New York,

Weimann, G. (2006). Terror on the Internet: The New Arena, the New Challenges . Washington, DC: United States Institute of Peace,

Wolcott, P. and Goodman, S. (2000), "The Internet in Turkey and Pakistan: A Comparative Analysis.” 145. Palo Alto, CA: Center for International Security and Cooperation, Stanford University. 